\title{
The Opoka-Rock from the Mesozoic/Neogene Contact Zone in the Bełchatów Lignite Deposit - Characteristics of a Petrographic Nature and as a Raw Material
}

\author{
Agnieszka Pękala \\ 1 Rzeszów University of Technology, Aleja Powstańców Warszawy 12, 35-959 Rzeszów, Poland \\ e-mail: apekala@prz.edu.pl
}

\begin{abstract}
During the exploitation of the Bełchatów lignite deposit at the point of contact between the Mesozoic substrate and Neogene deposits, the rocks of different petrographic composition were found. The group of rocks with transitional features between carbonate and silica rocks were called opoka-rock. This article presents the current state of knowledge on the geological conditions pertaining to the occurrence of the Bełchatów opoka-rock, and on its petrographic and chemical characteristics. An analysis was also carried out to determine the physical, mechanical as well as raw-material properties, as well as the related issue of potential utilisation.
\end{abstract}

Keywords: carbonate-siliceous rock, contact zone, Bełchatów, phosphorus removal, reactive material

\section{INTRODUCTION}

The Bełchatów lignite deposit is among the tectonic and opencast deposits located in central Poland. The mine exploiting it has a development policy assuming, not only the working of the main raw material which is lignite, but also the identification and management of accompanying minerals. The rocks from the Mesozoic-Neogene contact zone in the deposit are also mentioned in a broad group of the accompanying minerals at Bełchatów [RatajczakT., Hycnar E., 2017].

The work described in this paper is thus the sample characterisation of the so-called opokarock, which proves to be a transitional rock between carbonate and those of a silica character. This kind of rock has mainly been recognised in the Upper Cretaceous formations of the (TuronianConacian-Santonian) coal complex, or else a clastic-carbonate (Campanian and Maastrichtian) complex. The white-coloured opoka-rocks and marly opoka-rocks form a thick-set series of the carbonate complex, also coinciding with cherts locally. Marly and sandy opoka-rocks form alternate layers in the clastic-carbonate complex. Among them, marls with phosphate rock, sandstones and silty sandstones with glauconite could also be found (Figure.1).

The genesis of the sediments from the contact zone of the Mesozoic substrate and the early Neogene deposits coincides with the decline of the Cretaceous and early Palaeocene. The Mesozoic sedimentation cycle and folded corrugated structure of Jurassic and Cretaceous rocks was completed during the tectonic movements of the Laramie phase [Ratajczak T. et al 2002]. The Mesozoic relief of the Bełchatów region, formed as a result of the Laramie movements, underwent very strong peneplenisation in the Paleogene. As a result, the cover of Cretaceous deposits in the western and south-western areas of the region under study was destroyed completely. In turn, on the structures of the Radomszczański Belt and Łękińska Brachyanticline, strong denudation of the leading parts of the above structures led to the older deposits being uncovered. The peneplenisation period probably lasted throughout the entire Paleogene, as no sediments found in the Bełchatów region are indicative of the extent of the upper-Eocene transgression. The ingress of the Upper Oligocene reservoir could only have been of a marginal significance. Only the more 


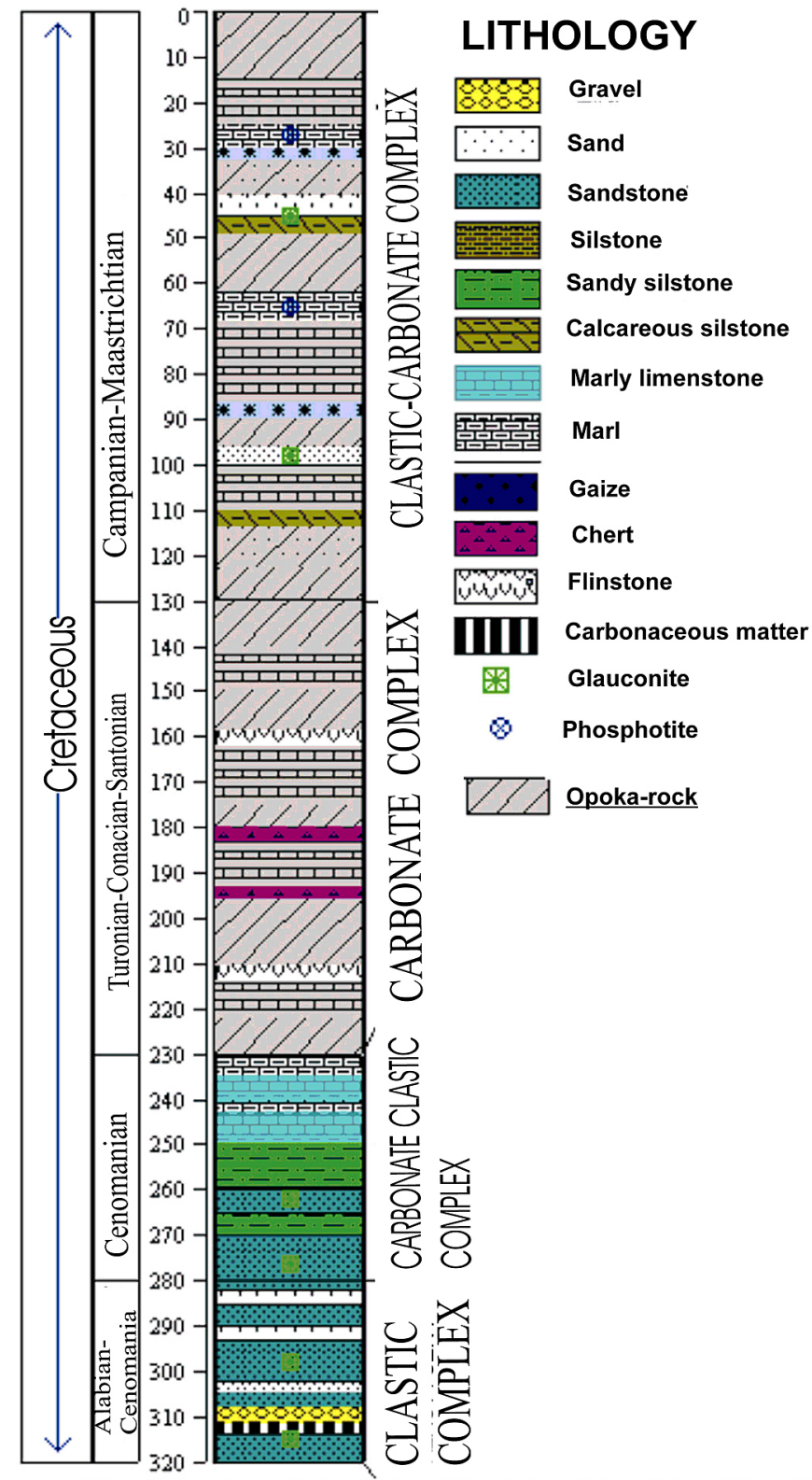

Fig. 1. Schematic lithostratigraphic profile of Cretaceous sediments of the Bełchatów lignite deposit in the Szczrcow field.

erosion-resistant silificated sponge and reef limestones of the Upper Jurassic was preserved from before the destruction. The stabilisation of the Mesozoic and the older deeper-lying orogen occurred shortly after the disappearance of the Laramie movements [Ciuk E., Piwocki M.,1980].

\section{MATERIALS AND METHODS}

The work described in this paper is thus a 28-sample characterisation of the opoka-rock, derived from drilling cores of the Szczerców field and southern slope of the open pit. The age of the studied deposits from the Mesozoic-Neogene contact zone is assessed as Maastrichtian.

The phase methods were used in order to uniquely identify the crystalline components of the studied rocks. The mineralogical and petrographic investigations were performed using Olympus BX-51 polarizing microscope. The studies of the chemical composition was determined by means of atomic absorption spectroscopy (AAS) using Philips PU 9100Xi Camera SX-100 spectrometer and an atomic emission spectroscopy with inductively coupled plasma ICP using Ultima 2 Horiba Jobin Yvon. Chemical analyses were carried out and the content of some 
elements: $\mathrm{Pb}, \mathrm{Cr}, \mathrm{Cd}, \mathrm{Ni}, \mathrm{Zn}, \mathrm{Cu}, \mathrm{Co}, \mathrm{As}, \mathrm{Sr}, \mathrm{Ba}$, $\mathrm{Zr}$ was determined in the studied opoka- rocks. The geomechanical properties were determined in accordance with the current standards.

\section{RESULTS AND DISCUSSION}

\section{Characteristics of the opoka-rocks}

The opoka-rock from Bełchatów is of a white, slightly creamy colour, only taking on a light-grey shade in a few cases. It produces a characteristic metallic sound when hit by a hammer. Treatment with $10 \% \mathrm{HCl}$ leaves the insoluble silica skeleton intact as the structure is micrite-organogenic or micrite-detrital. The texture is compact, locally showing a directional character. The main minerals are those of the $\mathrm{SiO}_{2}$ group, and studies have shown that the amount and type of silica mineral phase depends on the petrographic type of a rock. A distinction is drawn between the rocks in which the silica occurs in the form of Opal type A and CT (cristobalite- trydimite). The detritic quartz of the aleurite and pelite fraction occurring in them accounts for between 1 and about $10 \%$. The rocks called decalcified opoka-rocks were the second type determined to exist. The X-ray examination confirmed that the silica forming it is a chalcedony. The mineral is developed in the form of long fibres, arranged concentrically and radially, forming the skeleton. There are also short chalcedony fibres forming the rims around the quartz grains. Other than silica, carbonate minerals are found to be the essential component of the opoka-rocks. Calcite in the form of a micrite and an opal substance form the rocky background to these rocks. In addition, carbonates are shown to be built by numerous bioclasts, represented mainly by the shells of foraminiferans, as well as the fragments of molluscs shells and echinoderms. In turn, in the decalcified opoka-rocks, the carbonate minerals are shown to be an accessory component located in the pore spaces between the chalcedony aggregates [Gilarska et al. 2005].

The accessory minerals in the opoka-rocks are represented by muscovite plaques, as well as glauconite and pyrite. Heavy minerals here are represented by zirconium, rutile and tourmaline. Clayey and opaque ore minerals were only found in the decalcified opoka-rocks - see Figure 2.

A characteristic feature of the rocks from the Mesozoic-Neogene contact zone under discussion is the signs of silification they show. Silica replaces the carbonates in organic debris and cemented cracked crumbs, thus conferring increased hardness [Pękala et al., 2013].

Chemical analyses (Table 1) confirmed that silica is the dominant chemical component, which ranges in the average content from 50.1\% wt. in the opoka-rocks to $84.52 \%$ wt. in the decalcified version. The share of $\mathrm{CaO}$ in the opoka-rocks is $35.12 \%$ wt., while in the decalcified opokarocks, the traces of carbonates not exceeding $1 \%$ wt. were noted. Among other components, $\mathrm{Al}_{2} \mathrm{O}_{3}$ represents noteworthy content, indicative of the presence of clayey minerals in the rocks. Among the trace elements, strontium is noteworthy, being

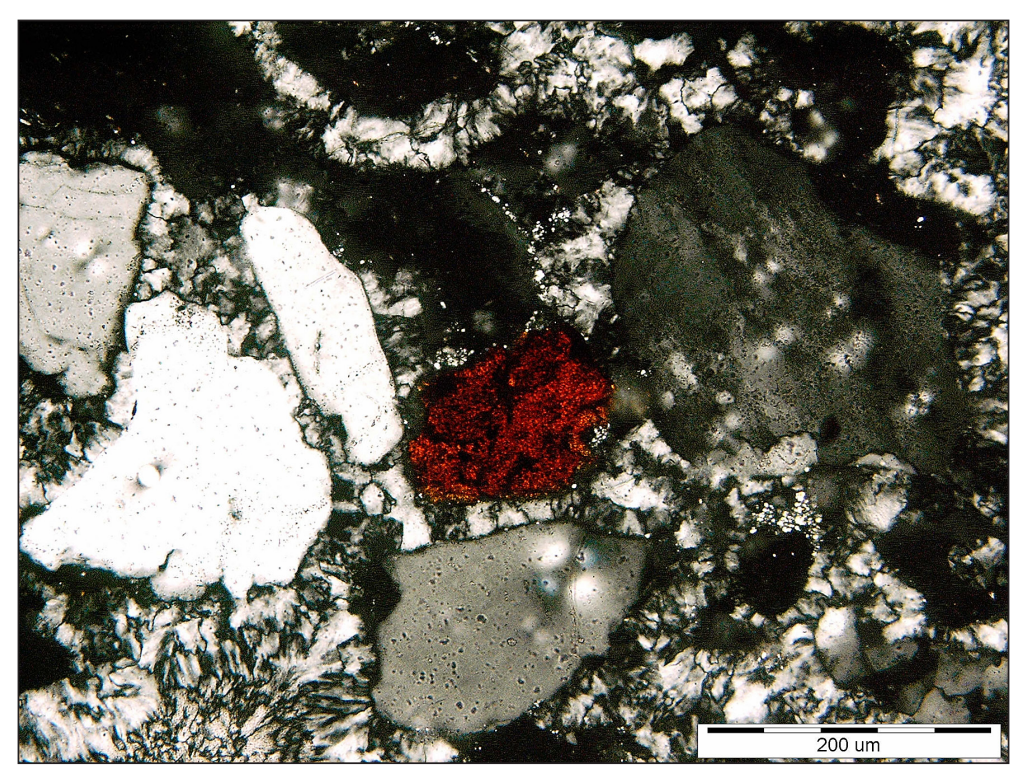

Fig. 2 Opaque ore minerals in the decalcified opoka-rocks. Polarizing microscope 2P 
Table 1. Chemical components of opoka rock and decalcified opoka - rock [wt.\%] (average value)

\begin{tabular}{|c|c|c|}
\hline \multirow{2}{*}{$\begin{array}{c}\text { Chemical component } \\
{[\text { wt.\%] }}\end{array}$} & \multicolumn{2}{|c|}{ Rock name } \\
\cline { 2 - 3 } & Opoka-rock & $\begin{array}{c}\text { Decalcified } \\
\text { opoka-rock }\end{array}$ \\
\hline $\mathrm{SiO}_{2}$ & 50.1 & 84.52 \\
\hline $\mathrm{CaO}$ & 35.12 & 0.82 \\
\hline $\mathrm{TiO}_{2}$ & 0.06 & 0.001 \\
\hline $\mathrm{Al}_{2} \mathrm{O}_{3}$ & 3.52 & 2.63 \\
\hline $\mathrm{Fe}_{2} \mathrm{O}_{3}$ & 0.8 & 1.74 \\
\hline $\mathrm{MgO}_{\mathrm{MnO}}$ & 0.4 & 0.61 \\
\hline $\mathrm{Na}_{2} \mathrm{O}$ & 0.01 & 0.001 \\
\hline $\mathrm{K}_{2} \mathrm{O}$ & 0.06 & 0.02 \\
\hline $\mathrm{P}_{2} \mathrm{O}_{5}$ & 0.45 & 0.20 \\
\hline
\end{tabular}

- means the content below the detection limi

present in the concentrations between $295 \mathrm{mg} / \mathrm{kg}$ in the opoka-rocks and $362 \mathrm{mg} / \mathrm{kg}$ in the decalcified form (Table 2).

The physical and mechanical parameters investigated suggest that thr differences between the petrographic varieties of the rocks are considerable. The average values for apparent density are of 1.92 and $1.37\left[\mathrm{~g} / \mathrm{cm}^{3}\right]$ in the opokarock and decalcified opoka-rock, respectively, while the values for specific density are of 2.45 and $2.59\left[\mathrm{~g} / \mathrm{cm}^{3}\right]$. In the opoka-rocks of greater density, the compressive strength in the air-dried state is also greater. The value for this parameter is $51 \mathrm{MPa}$, while in the decalcified opoka-rocks it amounts to $24.7 \mathrm{MPa}$. The reverse situation applies in relation to porosity, which equals 23.8 [ $\%$ vol.] in the typical rocks, as well as 44.2 [\% vol.] in the samples of the version of the rock.

This phenomenon can be explained by the mineral changes taking place as these rocks formed. The content of water or porosity decreases in the rocks as a result of the transition of Opal A to cristobalite - tridymite opal, and then to chalcedony or quartz. However, their density and strength parameters increase. The increase of porosity in the decalcified opoka-rocks is undoubtedly the result of the descaling processes involving these rocks.
The analysis of the test results allows to draw a conclusion that it is not only the quantity, but also the type, of silica mineral phases that affects the geotechnical parameters of the rocks studied. With the increase in the value of the crystallinity coefficient (CI), the values for the parameters such as compressive strength in the air-dried state and apparent density are greater, while porosity is lower [Pękala A., 2015].

\section{Current directions of use of opoka-rocks}

Thus far, opoka-rocks have mainly been used in the construction of religious, defensive and residential buildings, owing to their ease of exploitation. According to the resource balance for the mineral deposits in Poland dating back to 2017, opoka-rocks are included among the types of stones meeting the relevant requirements for the production of broken aggregate and stone elements for roads and construction, for the production of blocks and slabs and as a stone walling material. Spread across 11 deposits, the total resources of the rock equal to $13,192,000$ tonnes. The presence of this kind of rock has mainly been confirmed in the eastern Poland, where with 9 sites in Lublin (Lubelskie) Province alone. The total recoverable geological resources in that region amount to 4,283,000 tonnes. In addition, the deposits of opoka-rock are known from Rożniatów in Łódź (Łódzkie) voivodeship, where $7,700,000$ tonnes are found; as well as Cisowa in Podkarpackie, where some 1,209,000 tonnes are present [Resource Balance 2018]. The estimates and production resources from the Bełchatów deposit for opoka are amount to $100-150,000 \mathrm{~m}^{3}$ per year, with the figure for the decalcified form being several million $\mathrm{m}^{3}$.

The research carried out in recent years on the use of new rock raw materials as sorbents in environmental protection is increasingly pointing at the possibility of the opoka-rocks gaining use in this way. The literature data indicate that when used as an additional technological element,

Table 2. The concentration scope of determined elements in the opoka - rock and decalcified opoka - rock (average value)

\begin{tabular}{|c|c|c|c|c|c|c|c|c|c|c|c|c|c|}
\hline \multirow{2}{*}{ Rock name } & \multicolumn{10}{c|}{ Elements $[\mathrm{mg} / \mathrm{kg}]$} \\
\cline { 2 - 31 } & $\mathrm{Pb}$ & $\mathrm{Cr}$ & $\mathrm{Cd}$ & $\mathrm{Ni}$ & $\mathrm{Zn}$ & $\mathrm{Cu}$ & $\mathrm{Co}$ & $\mathrm{As}$ & $\mathrm{Sr}$ & $\mathrm{Ba}$ & $\mathrm{Zr}$ & $\mathrm{Th}$ & $\mathrm{U}$ \\
\hline Opoka -rock & 3.2 & 6.7 & 0.30 & 4.74 & 7.53 & 4.50 & 0.85 & 0.93 & 295 & 153 & 33 & 1.53 & 1.38 \\
\hline $\begin{array}{l}\text { Decalcified } \\
\text { opoka-rock }\end{array}$ & - & 0.05 & 2.34 & - & 1.39 & 3.6 & 0.01 & - & 362 & 41 & 7.5 & 0.45 & 1.13 \\
\hline
\end{tabular}

- means the content below the detection limit 
they give better results in removing total phosphorus from domestic waters and wastewaters [Jóźwiakowski K. et al. 2017]. The capacity to bind phosphorus noted for opoka-rock as a result of laboratory tests is between 12.3 and $25.5 \mathrm{mg}$ P-PO4 $\cdot \mathrm{g}^{-1}$ [Bus A. and Karczmarczyk A., 2014]. In addition, these rocks manifest a high efficiency of removal in the case of iron, manganese and coli bacteria, as well as low efficiency where the removal of psychro- and mesophilic bacteria is concerned [Marzec M. et al. 2017].

Due to the number and phase nature of the minerals from the $\mathrm{SiO}_{2}$ group present within them, the Bełchatów opoka-rocks from the Mesozoic-Neogene contact zone have a potential to be used, inter alia, in the production of Portland cement as a clinker component [Hycnar E. and Pękala A., 2011]. The sorption abilities have been noted over only a narrow range in the case of the decalcified opoka-rocks. The data established in this regard include:

- specific surface area (BET): $39 \mathrm{~m}^{2} / \mathrm{g}$,

- sorption (CEC): 63 mval / 100 g,

- sorption of transformed oil:

- 0-12 mm fraction: $46.7 \%$ (at $\mathrm{pH} 4$ ) and $38.7 \%$ (at $\mathrm{pH} 8$ ),

- 1-3 mm fraction: $32.16 \%$ (at $\mathrm{pH} 4$ ) and $24.3 \%$ (at pH 8) [Geological Department of the Bełchatów Mine, 2015].

It would also seem that the relatively low content of $\mathrm{CaO}$ in relation to the requirements imposed for the lime fertilisers, precludes this kind of use of the rocks in agriculture [Pękala A., 2013].

\section{CONCLUSIONS}

The Bełchatów opoka-rocks from the Mesozoic-Neogene contact zone display petrographic differentiation. The research carried out among them demonstrated the presence of the typical opoka-rocks as well as the opoka of a decalcified nature. There were also the opoka-rocks that had come under the influence of secondary mineral processes, mainly silification [Pękala A., 2013]. The main component in the group of rocks studied is $\mathrm{SiO}_{2}$, the average contents of which were $50.1 \%$ wt. in the opoka-rocks and $84.52 \%$ in the decalcified kind of opoka. The differentiated $\mathrm{CaO}$ content is noteworthy. Among the trace elements, strontium was present at the highest concentration, with the elevated concentration in the decalcified version of opoka, capable of being explained by reference to the advanced process of descaling. In the course of weathering processes, strontium is easily sorbed by clayey minerals, and organisms that form calcareous skeletons.

The nature of the discussed opoka-rocks as raw materials remains rather poorly understood. The current state of research in this area is incomplete, so the use as potential pro-environmental materials cannot be precluded as yet. The diversified petrographic nature of the group of transitional rocks considered here points at the necessity for more basic (mainly chemical) research to be carried out, in advance of any planned technological research.

\section{REFERENCES}

1. Bus A., Karczmarczyk A. 2014. Charakterystyka skały wapienno-krzemionkowej opoki w aspekcie jej wykorzystania jako materiału reaktywnego do usuwania fosforu z wód i ścieków [Properties of lime-siliceous rock opoka as a reactive material to remove phosphorus from water and wastewater]. Infrastruktura i Ekologia Terenów Wiejskich. No. II/1/2014, PAN Oddział w Krakowie p. 227-238. DOI: http://dx.medra. org/10.14597/infraeco.2014.2.1.017

2. Ciuk E., Piwocki M. 1980.Geologia trzeciorzędu w rowie Kleszczowa i jego otoczeniu. Przewodnik LII Zjazdu Polskiego Towarzystwa Geologicznego, Bełchatów. Wydawnictwo Geologiczne. Warszawa

3. Gilarska A., Stachura E. 2005. Charakter mineralogiczno - petrograficzny skał krzemionkowych ze strefy kontaktu trzeciorzęd - mezozoik w złożu węgla brunatnego "Bełchatów". Zeszyty Politechniki Śląskiej, seria Górnictwo, zesz. 269.

4. Hycnar E., Pękala A. 2011. Opoka-rock from the Bełchatów lignite deposit and the possibilites of it's practical use. Journal of Civil Engineering, Environment and Architecture. 276-54 (2-11).

5. Jóźwiakowski K., Gajewska M., Pytka A., Marzec M., Gizińska-Górna M., Jucherski A., Walczowski A., Nastawny M., Kamińska A., Baran S. 2017. Influence of the particle size of carbonate-siliceous rock on the efficiency of phosphorous removal from domestic wastewater. Ecological Engineering, Vol. 98, 290-296

6. Marzec M. Pieńko A., Gizińska - Górna M., Pytka A., Jóźwiakowski K., Sosnowska B, Kamińska A., Listosz A. 2017. The use of carbonate-silica rock (opoka) to remove iron, manganese and indicator bacteria from groundwater. Journal of water and land development. No. 34 (VII-IX). 197-204. DOI: $10.1515 /$ jwld-2017-0054 
7. Pękala A. 2015. The influence of siliceous mineral phases on the mechanical properties of transitional rocks in the Bełchatów lignite deposit. Arch Civ Eng. 61, 4.

8. Pękala A., Hycnar E. 2013. Opoki ze złoża węgla brunatnego Bełchatów - charakterystyka petrograficzna i możliwości wykorzystania. [W:] Sorbenty mineralne. Surowce, Energetyka, Ochrona Środowiska, Nowoczesne Technologie. Wyd. AGH, 337-345.

9. Ratajczak T., Hycnar E. 2017. Geological and raw material aspects of the development of accompany- ing minerals. Vol 1. IGSMiE PAN - Wydawnictwo, Kraków 2017

10. Ratajczak T., Kosk I., Pabis J. 2002. Weathered sediments from the Mesozoic-Tertiary contact zone in the Bełchatów lignite deposit - their lithology, raw material character and possibility of use [in Polish]. Materiały XII Konferencji z cyklu Aktualia i perspektywy gospodarki surowcami mineralnymi. Świeradów - Zdrój. Sympozja i Konferencje nr 56. Wydawnictwo IGSMiE PAN, Kraków.

11. Resource Balance in Poland 2018. PIG-PIB Warszawa. 